\title{
Acid-base balance parameters of follicular fluid and venous blood in cattle
}

\author{
Eva Indrova ${ }^{1}$, Michaela Andrlikova $^{1}$, Vladislav Bina ${ }^{2}$, Radovan Dolezel $^{1}$,

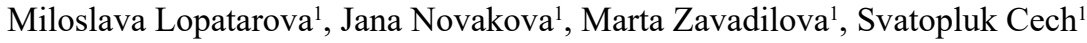 \\ ${ }^{1}$ University of Veterinary and Pharmaceutical Sciences Brno, Faculty of Veterinary Medicine, \\ Ruminant and Swine Clinic, Brno, Czech Republic \\ ${ }^{2}$ University of Economics, Prague, Faculty of Management, Department of Exact Methods, \\ Jindrichuv Hradec, Czech Republic \\ Received September 27, 2019 \\ Accepted January 28, 2020
}

\begin{abstract}
The study aimed to compare differences of physiological acid-base balance (ABB) parameters in follicular fluid (FF) and venous blood (VB) and to evaluate ABB parameters in FF collected from different ovarian follicles in dairy cows and heifers. The ABB parameters $\left(\mathrm{pH}, \mathrm{pCO}_{2}, \mathrm{pO}_{2}\right.$, $\mathrm{HCO}_{3}{ }^{-}$and base excess (BE)) in the $\mathrm{FF}$ of the preovulatory follicle, of the dominant follicle on the 9 th day of the cycle and of the superovulatory estrous follicles were compared to VB. Similarly, the dynamics of the $\mathrm{ABB}$ profile in $\mathrm{FF}$ and $\mathrm{VB}$ were monitored in repeated sampling in a group of heifers stimulated by follicle-stimulating hormone ( $\mathrm{FSH})$. Higher values of $\mathrm{pH}$ and $\mathrm{pO}_{2}$ and lower values of $\mathrm{pCO}_{2}, \mathrm{HCO}_{3}{ }^{-}$and $\mathrm{BE}$ were found in $\mathrm{FF}$ compared to $\mathrm{VB}$ in all experiments. Laterality of ovaries, time of sampling, ovarian activity or stimulation of the follicular development by FSH did not significantly influence ABB parameters. We found higher $\mathrm{pH}(7.392 \pm 0.027$ vs. $7.364 \pm 0.032)$ and $\mathrm{pO}_{2}(13.83 \pm 2.20 \mathrm{kPa}$ vs. $4.50 \pm 0.67 \mathrm{kPa})$, lower $\mathrm{pCO}_{2}(5.70 \pm 0.39$ $\mathrm{kPa}$ vs. $6.54 \pm 0.61 \mathrm{kPa}), \mathrm{HCO}_{3}^{-}(25.51 \pm 1.52 \mathrm{mmol} / \mathrm{l}$ vs. $26.86 \pm 2.12 \mathrm{mmol} / \mathrm{l})$ and $\mathrm{BE}$ $(1.14 \pm 1.57 \mathrm{mmol} / 1$ vs. $1.95 \pm 2.2 \mathrm{mmol} / \mathrm{l})$ in $\mathrm{FF}$ compared to $\mathrm{VB}$ in all non-stimulated cows. Similar relationships between FF and VB were found in all FSH stimulated cows. The study provides as yet unknown knowledge on the physiology of follicular fluid in cattle.
\end{abstract}

$\mathrm{BE}$, follicle, $\mathrm{HCO}_{3}^{-}$, heifer, $\mathrm{pCO}_{2}, \mathrm{pH}$

Follicular fluid (FF) consists of serum transudate and also of locally produced substances, which are related to the metabolic activity of the follicular cells (Gérard et al. 2002). Follicular fluid can be used as a good index for the functional status of the ovarian follicle, because of its intimate contact with the oocyte and granulosa cells (Eis sa 1996). Follicular fluid plays a major role in the autocrine and paracrine regulation and also in the physiological, biochemical and metabolic aspects of the nuclear and cytoplasmatic maturation of the oocyte and the process of ovulation (Hafez 2000). Follicular fluid from cattle is usually collected by ultrasound-guided transvaginal aspiration (TVFA), when various biochemical or endocrine examinations of FF are performed (Vos et al. 1994; Kohram et al. 1998; Landau et al. 2000; Walters et al. 2002; de Castro e Paula et al. 2008; Shehab-El-Deen et al. 2010; Moallem et al. 2011). However, FF sampling for acid-base balance (ABB) and gas analysis from live animals is rarely described (Berg et al. 2003, 2005; Cech et al. 2007; de Castro e Paula et al. 2008; Indrova et al. 2017), perhaps due to the technical difficulties involved in FF sampling (Cech et al. 2011). Acid-base balance in the body fluids is an impressive illustration of homeostasis and is one of the most vigorously regulated variables of the body. The relatively constant hydrogen ion concentration $\left[\mathrm{H}^{+}\right]$is the result of a balance between acids and bases. Under normal conditions, acids or bases are added continuously to the body fluids, either because of their ingestion or as a result of their production in cellular metabolism. Mechanisms for maintenance of the relatively constant $\left[\mathrm{H}^{+}\right]$in body fluids are provided by chemical buffer systems, the respiratory system, and the kidneys (Reece 2015). 
Physiological ABB parameters of venous blood (VB) of dairy cattle are well known: 7.38-7.43; 5.2-6.4 kPa; $-0.5-4.5$ and $23.5-27 \mathrm{mmol} / 1$ for $\mathrm{pH}, \mathrm{pCO}_{2}$, base excess (BE) and $\mathrm{HCO}_{3}^{-}$, respectively (Pechova et al. 2015). The values of ABB parameters in FF are not clearly defined. Several articles in human medicine have dealt with these factors (Shalgi et al. 1972; Daya 1988; Imoedemhe et al. 1993); however, they have specifically focused only on concentrations of carbon dioxide and $\mathrm{pH}$ in FF.

Therefore, the aim of this study was to compare differences of physiological acid-base balance parameters in follicular fluid and venous blood, and to evaluate ABB parameters in FF collected from follicles of different origin in dairy cows and heifers.

\section{Materials and Methods}

Animals and treatments

The study was divided into 4 experiments according to animal treatment. The FF from the defined follicle(s) and VB were obtained for acid-base balance analysis in each experiment. Experimental animals involved in experiments 1-3 were part of a commercial dairy farm (700 Holstein cows). Non-pregnant cows yielding 25-30 kg milk daily at a body weight of 600-700 kg were kept and managed under normal farm conditions in free stables. Cows were fed by total mixed ration (TMR) containing corn silage, alfalfa haylage, cut straw and concentrates. The animals used in experiment 4 were Holstein heifers at the age of 15 months and an average body weight of $430 \pm 15 \mathrm{~kg}$. The heifers were kept at the Ruminant and Swine Clinic of the Faculty of Veterinary Medicine Brno and fed hay and concentrates. All experiments were approved by the Institutional Animal Care Committee (experiment MSMT-27669/2019-9).

Experiment 1: Oestrus synchronized with cloprostenol

The experiment was performed in 22 cows bearing corpus luteum. The sampling was carried out in cows showing oestrus on day 3 after administration of cloprostenol (500 $\mu \mathrm{g}$ i.m. pro toto, Oestrophan, Bioveta, a. s., Ivanovice na Hane, Czech Rep.). Follicular fluid was obtained from the largest follicle which was considered to be the preovulatory follicle.

Experiment 2: Luteal phase in an oestrous cycle synchronized with cloprostenol

The sampling was carried out in 22 cows on the $9^{\text {th }}$ day after oestrus. Oestrus was induced by the administration of cloprostenol (see above). Follicular fluid was obtained from the largest follicle which was considered to be the dominant follicle.

Experiment 3: Oestrus synchronized with cloprostenol after stimulation of the follicular growth with follicle-stimulating hormone (FSH)

The sampling was carried out in 11 cows. Cows bearing corpus luteum were synchronized by cloprostenol (see above). Seven days later, the dominant follicles were ablated by ultrasound-guided transvaginal aspiration to start the new follicular wave. Two days later (day 0, D0), stimulation using FSH was initiated. A total dose of $345 \mu \mathrm{g}$ FSH (Stimufol ${ }^{\circledR}$, Ulg, FMV, Liége, Belgium) was administered intramuscularly (IM) at eight decreasing

Table 1. Treatment schedule.

\begin{tabular}{lccc}
\hline Day & Hours & Treatment & Dose \\
\hline D-9 & & cloprostenol & $500 \mu \mathrm{g}$ \\
D-2 & & TVFA & \\
D 0 & 0 & FSH & $55 \mu \mathrm{g}$ \\
& 12 & FSH & $55 \mu \mathrm{g}$ \\
D1 & 24 & FSH & $50 \mu \mathrm{g}$ \\
& 36 & FSH & $45 \mu \mathrm{g}$ \\
D2 & 48 & FSH + cloprostenol & $35 \mu \mathrm{g}+500 \mu \mathrm{g}$ \\
& 60 & FSH & $35 \mu \mathrm{g}$ \\
D3 & 72 & FSH & $35 \mu \mathrm{g}$ \\
& 84 & FSH & $35 \mu \mathrm{g}$ \\
\hline
\end{tabular}

TVFA $=$ transvaginal aspiration of all follicles exceeding $5 \mathrm{~mm}$ $\mathrm{FSH}=$ superstimulation using follicle-stimulating hormone doses at $12 \mathrm{~h}$ intervals (D0-D3) (Table 1). Oestrus was induced by the cloprostenol treatment (see above) at D2. The sampling was carried out in cows showing oestrus on D4 (i.e. 2 days after the cloprostenol treatment). Two samples of FF (one sample from each ovary) were obtained from the follicles which were considered to be the superovulatory follicles.

Experiment 4: Follicle development at the end of the follicle stimulation with FSH (superovulation protocol) during the luteal phase of the oestrous cycle

Ten Holstein heifers were synchronized and superstimulated as in experiment 3, except cloprostenol treatment in order to ensure FF for repeated collection. The sampling was carried out on D3 (it means the last day of FSH treatment) in the 
morning (time $0, \mathrm{~T} 0$ ) and then 24 and $36 \mathrm{~h}$ later (T24 and T36). Two samples of FF (one sample from each ovary) were obtained at each sampling from the follicles which were considered to be the stimulated follicles.

Follicular fluid sampling and analysis

Follicular fluid was collected by TVFA as previously described (Indrova et al. 2017) using a device for aspiration of FF for ABB analysis (Cech et al. 2013). The TVFA was performed after epidural anaesthesia ( $4 \mathrm{ml}, 2 \%$ lidocaine, Fatro, Ozzano Emilia, Italy), rectum evacuation and disinfection of the vulva and perineum. A real-time B-mode ultrasound machine (Aloka SSD-500, Tokyo, Japan), equipped with a convex ultrasound transducer (7.5 MHz, Aloka UST 9125, Tokyo, Japan) placed in a plastic holder was used to control the follicular aspiration. The probe holder was inserted as deep as possible into the fornix vaginae. The technician performing the procedure manipulated the ovary through the rectal wall and located the target follicle, for aspiration, on the scanner screen. The syringe holder, with the attached aspiration syringe and needle, was inserted into a guide tube and the needle was then inserted into the centre of the target follicle by manipulation of the end of the syringe holder. Then, a guide ring with a connecting rod and attached syringe piston were slowly pulled back, and the fluid was aspirated into the syringe. Modified glass syringes $(2 \mathrm{ml}$, Chirana, Stara Tura, Czech Republic) with $20 \mathrm{G}$ disposable needles were used for FF collection. Air bubbles were expelled from the syringes immediately after collection, syringes were capped with a rubber stopper and the syringes were stored on ice. The samples were analysed via the Radiometer ABL 800 Flex (Radiometer Medical ApS, Brønshøj, Denmark) within $2 \mathrm{~h}$ after collection, in experiment 4 immediately after collection. The samples were heated to $37^{\circ} \mathrm{C}$ according to the analyser settings. The values of $\mathrm{pH}, \mathrm{pCO}_{2}$ and $\mathrm{pO}_{2}, \mathrm{HCO}_{3}{ }^{-}$and $\mathrm{BE}$ were measured.

Blood sampling and analysis

Glass syringes with sodium heparin ( $2 \mathrm{ml}$, Chirana, Stara Tura, Czech Republic) were used to collect the blood samples for determination of blood gas, $\mathrm{pH}, \mathrm{HCO}_{3}^{-}$and $\mathrm{BE}$. Blood samples were collected from the jugular vein $(1.5 \mathrm{ml})$. The sample handling was the same as with FF.

Statistical analysis

Statistical analysis was done using the statistical software package R (R Core Team 2017). Significant differences between the values of ABB parameters in blood and FF were demonstrated in experiment 1 and 2 using paired Student's $t$-test. In experiments 3 and 4 a block study design for the evaluation was used, and detailed analysis was then performed in case of significant results using Tukey's multiple comparisons. The results are expressed in tables as the mean and standard deviation (SD). The difference was considered significant in the case of $P$-values lower than 0.05 .

\section{Results}

\section{Experiment 1}

Twenty-two FF samples from the oestrous follicle and 22 blood samples from the jugular vein were collected. Follicular fluid showed a significantly higher value of $\mathrm{pH}(P<0.05)$, lower $\mathrm{pCO}_{2}(P<0.001)$, higher $\mathrm{pO}_{2}(P<0.001)$, lower $\mathrm{HCO}_{3}^{-}(P<0.01)$ and lower $\mathrm{BE}$ $(P<0.01)$ compared to blood (Table 2$)$.

Table 2. Mean values of acid-base balance parameters in venous blood and oestrous follicular fluid in dairy cows.

\begin{tabular}{lccccc}
\hline & $\mathrm{pH}$ & $\mathrm{pCO}_{2}(\mathrm{kPa})$ & $\mathrm{pO}_{2}(\mathrm{kPa})$ & $\mathrm{HCO}_{3}-(\mathrm{mmol} / \mathrm{l})$ & $\mathrm{BE}(\mathrm{mmol} / \mathrm{l})$ \\
\hline Blood & $7.378 \pm 0.034^{\mathrm{a}}$ & $6.39 \pm 0.62^{\mathrm{a}}$ & $4.10 \pm 0.52^{\mathrm{a}}$ & $26.86 \pm 2.24^{\mathrm{a}}$ & $2.51 \pm 2.44^{\mathrm{a}}$ \\
$\mathrm{FF}$ & $7.398 \pm 0.030^{\mathrm{b}}$ & $5.63 \pm 0.40^{\mathrm{b}}$ & $13.07 \pm 2.49^{\mathrm{b}}$ & $25.60 \pm 1.81^{\mathrm{b}}$ & $1.34 \pm 1.90^{\mathrm{b}}$ \\
\hline
\end{tabular}

a,b - values with different superscripts within columns are significantly different $(P<0.05)$

Collected data are represented by the mean and standard deviation.

$\mathrm{FF}$ - follicular fluid, BE - base excess

\section{Experiment 2}

Twenty-two FF samples from the dominant follicle on the $9^{\text {th }}$ day of the cycle and 22 blood samples from the jugular vein were collected. Follicular fluid showed a significantly higher value of $\mathrm{pH}(P<0.001)$, lower $\mathrm{pCO}_{2}(P<0.001)$, higher $\mathrm{pO}_{2}(P<0.001)$, lower $\mathrm{HCO}_{3}$ $(P<0.001)$ and lower BE (tightly non-significant; $P<0.056)$ compared to blood (Table 3$)$. 
Table 3. Mean values of acid-base balance indices in venous blood and follicular fluid obtained from the dominant follicle on the 9th day of the cycle in dairy cows.

\begin{tabular}{lccccc}
\hline & $\mathrm{pH}$ & $\mathrm{pCO}_{2}(\mathrm{kPa})$ & $\mathrm{pO}_{2}(\mathrm{kPa})$ & $\mathrm{HCO}_{3}{ }^{-}(\mathrm{mmol} / \mathrm{l})$ & $\mathrm{BE}(\mathrm{mmol} / \mathrm{l})$ \\
\hline Blood & $7.350 \pm 0.023^{\mathrm{a}}$ & $6.68 \pm 0.58^{\mathrm{a}}$ & $4.94 \pm 0.52^{\mathrm{a}}$ & $26.86 \pm 2.05^{\mathrm{a}}$ & $1.40 \pm 1.82^{\mathrm{a}}$ \\
$\mathrm{FF}$ & $7.386 \pm 0.025^{\mathrm{b}}$ & $5.77 \pm 0.38^{\mathrm{b}}$ & $14.59 \pm 1.58^{\mathrm{b}}$ & $25.42 \pm 1.19^{\mathrm{b}}$ & $0.94 \pm 1.15^{\mathrm{a}}$ \\
\hline
\end{tabular}

a,b - values with different superscripts within columns are significantly different $(P<0.05)$

Collected data are represented by the mean and standard deviation.

$\mathrm{FF}$ - follicular fluid, BE - base excess

\section{Experiment 3}

Twenty-two FF samples from the oestrous follicle after stimulation with FSH from 11 cows (one sample from each ovary) and 11 blood samples from the jugular vein were collected. Follicular fluid showed a significantly lower value of $\mathrm{pCO}_{2}(P<0.001)$, higher $\mathrm{pO}_{2}(P<0.001)$, and lower $\mathrm{HCO}_{3}^{-}(P<0.05)$ compared to blood. The values of $\mathrm{pH}$ and $\mathrm{BE}$ in blood and FF were not significantly different. Indices of ABB did not differ between two samples of FF obtained from one cow (Table 4).

Table 4. Mean values of acid-base balance indices in venous blood and follicular fluid (FF1 - right ovary; FF2 - left ovary) obtained at the time of oestrus after superstimulation in dairy cows.

\begin{tabular}{lccccc}
\hline & $\mathrm{pH}$ & $\mathrm{pCO}_{2}(\mathrm{kPa})$ & \multicolumn{1}{c}{$\mathrm{pO}_{2}(\mathrm{kPa})$} & $\mathrm{HCO}_{3}{ }^{-}(\mathrm{mmol} / \mathrm{l})$ & $\mathrm{BE}(\mathrm{mmol} / 1)$ \\
\hline Blood & $7.402 \pm 0.019^{\mathrm{a}}$ & $6.57 \pm 0.68^{\mathrm{a}}$ & $3.81 \pm 0.17^{\mathrm{a}}$ & $29.85 \pm 3.02^{\mathrm{a}}$ & $4.79 \pm 2.68^{\mathrm{a}}$ \\
$\mathrm{FF} 1$ & $7.429 \pm 0.041^{\mathrm{a}}$ & $5.45 \pm 0.34^{\mathrm{b}}$ & $13.16 \pm 2.66^{\mathrm{b}}$ & $26.65 \pm 2.12^{\mathrm{b}}$ & $2.67 \pm 2.33^{\mathrm{a}}$ \\
$\mathrm{FF} 2$ & $7.428 \pm 0.031^{\mathrm{a}}$ & $5.51 \pm 0.41^{\mathrm{b}}$ & $14.10 \pm 1.60^{\mathrm{b}}$ & $26.83 \pm 2.19^{\mathrm{b}}$ & $2.82 \pm 2.29^{\mathrm{a}}$ \\
\hline
\end{tabular}

a,b - values with different superscripts within columns are significantly different $(P<0.05)$

Collected data are represented by the mean and standard deviation.

FF1 - follicular fluid obtain from right ovary; FF2 follicular fluid obtain from left ovary, FF - follicular fluid, $\mathrm{BE}$ - base excess

\section{Experiment 4}

Three samples from five superstimulated heifers (right ovary follicular fluid - FF1, left ovarian follicular fluid - FF2 and VB) obtained repeatedly at 0,24 , and $36 \mathrm{~h}$ were analysed for the changes of ABB indices. A significant increase $(P<0.05)$ of $\mathrm{pH}$ values in follicular fluid was observed in FF1 samples at $36 \mathrm{~h}$ (Table 5). The other values did not change during the experiment, similarly as in FF2 (Table 6). Only an increase of BE $(P<0.01)$ and $\mathrm{HCO}_{3}^{-}(P<0.05)$ values was found in the peripheral blood at $36 \mathrm{~h}$ (Table 7).

Table 5. Dynamics of acid-base balance indices in follicular fluid from the right ovary (FF1) after superstimulation in dairy heifers.

\begin{tabular}{lccccc}
\hline FF1 & $\mathrm{pH}$ & $\mathrm{pCO}_{2}(\mathrm{kPa})$ & $\mathrm{pO}_{2}(\mathrm{kPa})$ & $\mathrm{HCO}_{3}{ }^{-}(\mathrm{mmol} / \mathrm{l})$ & $\mathrm{BE}(\mathrm{mmol} / 1)$ \\
\hline T0 & $7.416 \pm 0.025^{\mathrm{a}}$ & $5.17 \pm 0.14^{\mathrm{a}}$ & $11.95 \pm 2.40^{\mathrm{a}}$ & $24.48 \pm 1.85^{\mathrm{a}}$ & $0.46 \pm 1.95^{\mathrm{a}}$ \\
$\mathrm{T} 24$ & $7.403 \pm 0.018^{\mathrm{a}}$ & $5.28 \pm 0.19^{\mathrm{a}}$ & $11.78 \pm 1.67^{\mathrm{a}}$ & $24.22 \pm 1.21^{\mathrm{a}}$ & $0.06 \pm 1.34^{\mathrm{a}}$ \\
$\mathrm{T} 36$ & $7.423 \pm 0.029^{\mathrm{b}}$ & $5.11 \pm 0.34^{\mathrm{a}}$ & $13.96 \pm 2.24^{\mathrm{a}}$ & $24.6 \pm 1.56^{\mathrm{a}}$ & $0.82 \pm 1.64^{\mathrm{a}}$ \\
\hline
\end{tabular}

a,b - values with different superscripts within columns are significantly different $(P<0.05)$

Collected data are represented by the mean and standard deviation.

FF1 - follicular fluid obtain from right ovary, BE - base excess; T0 - time 0, start of follicular fluid aspiration; T24 and T36 - aspiration of follicular fluid 24 and $36 \mathrm{~h}$ later 
Table 6. Dynamics of acid-base balance indices in follicular fluid from the left ovary (FF2) after superstimulation in dairy heifers

\begin{tabular}{lccccr}
\hline FF2 & $\mathrm{pH}$ & $\mathrm{pCO}_{2}(\mathrm{kPa})$ & $\mathrm{pO}_{2}(\mathrm{kPa})$ & $\mathrm{HCO}_{3}{ }^{-}(\mathrm{mmol} / \mathrm{l})$ & $\mathrm{BE}(\mathrm{mmol} / \mathrm{l})$ \\
\hline $\mathrm{T} 0$ & $7.420 \pm 0.023^{\mathrm{a}}$ & $5.18 \pm 0.17^{\mathrm{a}}$ & $10.64 \pm 1.09^{\mathrm{a}}$ & $24.74 \pm 1.71^{\mathrm{a}}$ & $0.84 \pm 1.79^{\mathrm{a}}$ \\
$\mathrm{T} 24$ & $7.402 \pm 0.014^{\mathrm{a}}$ & $5.21 \pm 0.20^{\mathrm{a}}$ & $11.68 \pm 1.33^{\mathrm{a}}$ & $23.80 \pm 1.29^{\mathrm{a}}$ & $-0.40 \pm 1.40^{\mathrm{a}}$ \\
$\mathrm{T} 36$ & $7.395 \pm 0.044^{\mathrm{a}}$ & $5.55 \pm 0.62^{\mathrm{a}}$ & $11.85 \pm 1.71^{\mathrm{a}}$ & $24.84 \pm 1.19^{\mathrm{a}}$ & $0.56 \pm 1.35^{\mathrm{a}}$ \\
\hline
\end{tabular}

a - values are not different $(P<0.05)$

Collected data are represented by the mean and standard deviation.

FF2 follicular fluid obtain from left ovary, BE - base excess; T0 - time 0, start of follicular fluid aspiration; $\mathrm{T} 24$ and T36 - aspiration of follicular fluid 24 and $36 \mathrm{~h}$ later

Table 7. Dynamics of acid-base balance indices in venous blood after superstimulation in dairy heifers.

\begin{tabular}{lccccc}
\hline Blood & $\mathrm{pH}$ & $\mathrm{pCO}_{2}(\mathrm{kPa})$ & $\mathrm{pO}_{2}(\mathrm{kPa})$ & $\mathrm{HCO}_{3}{ }^{-}(\mathrm{mmol} / \mathrm{l})$ & $\mathrm{BE}(\mathrm{mmol} / 1)$ \\
\hline T0 & $7.401 \pm 0.021^{\mathrm{a}}$ & $5.76 \pm 0.11^{\mathrm{a}}$ & $4.42 \pm 0.32^{\mathrm{a}}$ & $25.74 \pm 2.19^{\mathrm{a}}$ & $1.28 \pm 2.17^{\mathrm{a}}$ \\
$\mathrm{T} 24$ & $7.388 \pm 0.025^{\mathrm{a}}$ & $5.77 \pm 0.42^{\mathrm{a}}$ & $4.23 \pm 0.34^{\mathrm{a}}$ & $25.50 \pm 1.43^{\mathrm{a}}$ & $0.82 \pm 1.41^{\mathrm{a}}$ \\
$\mathrm{T} 36$ & $7.402 \pm 0.025^{\mathrm{a}}$ & $5.91 \pm 0.43^{\mathrm{a}}$ & $4.22 \pm 0.18^{\mathrm{a}}$ & $27.04 \pm 1.92^{\mathrm{b}}$ & $2.36 \pm 1.85^{\mathrm{b}}$ \\
\hline
\end{tabular}

a,b - values with different superscripts within columns are significantly different $(P<0.05)$

Collected data are represented by the mean and standard deviation.

$\mathrm{BE}$ - base excess; T0 - time 0, start of follicular fluid aspiration; T24 and T36 - aspiration of follicular fluid 24 and $36 \mathrm{~h}$ later

The results of the $1^{\text {st }}$ and $2^{\text {nd }}$ experiments and the $3^{\text {rd }}$ and $4^{\text {th }}$ experiments were compound together to increase the number of samples. Thus, the relationship between blood and FF ABB indices in non-stimulated and FSH-stimulated cows can be evaluated. The values of all ABB indices were significantly different between FF and VB in these two groups. Follicular fluid showed a significantly higher $\mathrm{pH}$ value $(P<0.001, P<0.01)$, lower $\mathrm{pCO}_{2}(P<0.001, P<0.001)$, higher $\mathrm{pO}_{2}(P<0.001, P<0.001)$, lower $\mathrm{HCO}_{3}^{-}(P<0.001$, $P<0.001)$ and lower BE $(P<0.01, P<0.01)$ compared to blood (Tables 8 and 9$)$.

Table 8. Mean values of acid-base balance indices in blood and FF obtained from non-stimulated follicles in dairy cows.

\begin{tabular}{lccccc}
\hline & $\mathrm{pH}$ & $\mathrm{pCO}_{2}(\mathrm{kPa})$ & \multicolumn{1}{c}{$\mathrm{pO}_{2}(\mathrm{kPa})$} & $\mathrm{HCO}^{-}(\mathrm{mmol} / \mathrm{l})$ & $\mathrm{BE}(\mathrm{mmol} / 1)$ \\
\hline Blood & $7.364 \pm 0.032^{\mathrm{a}}$ & $6.54 \pm 0.61^{\mathrm{a}}$ & $4.50 \pm 0.67^{\mathrm{a}}$ & $26.86 \pm 2.12^{\mathrm{a}}$ & $1.95 \pm 2.20^{\mathrm{a}}$ \\
$\mathrm{FF}$ & $7.392 \pm 0.027^{\mathrm{b}}$ & $5.70 \pm 0.39^{\mathrm{b}}$ & $13.83 \pm 2.20^{\mathrm{b}}$ & $25.51 \pm 1.52^{\mathrm{b}}$ & $1.14 \pm 1.57^{\mathrm{b}}$ \\
\hline
\end{tabular}

a,b - values with different superscripts within columns are significantly different $(P<0.05)$

Collected data are represented by the mean and standard deviation.

$\mathrm{FF}$ - follicular fluid, $\mathrm{BE}$ - base excess

Table 9. Mean values of acid-base balance indices in blood and FF obtained from superstimulated follicles in dairy cows.

\begin{tabular}{lccccc}
\hline & $\mathrm{pH}$ & $\mathrm{pCO} 2(\mathrm{kPa})$ & $\mathrm{pO} 2(\mathrm{kPa})$ & $\mathrm{HCO}_{3}{ }^{-}(\mathrm{mmol} / \mathrm{l})$ & $\mathrm{BE}(\mathrm{mmol} / \mathrm{l})$ \\
\hline Blood & $7.364 \pm 0.032^{\mathrm{a}}$ & $6.54 \pm 0.61^{\mathrm{a}}$ & $4.50 \pm 0.67^{\mathrm{a}}$ & $26.86 \pm 2.12^{\mathrm{a}}$ & $1.95 \pm 2.20^{\mathrm{a}}$ \\
$\mathrm{FF}$ & $7.392 \pm 0.027^{\mathrm{b}}$ & $5.70 \pm 0.39^{\mathrm{b}}$ & $13.83 \pm 2.20^{\mathrm{b}}$ & $25.51 \pm 1.52^{\mathrm{b}}$ & $1.14 \pm 1.57^{\mathrm{b}}$ \\
\hline
\end{tabular}

a,b - values with different superscripts are significantly different $(P<0.05)$

Collected data are represented by the mean and standard deviation.

FF1 - follicular fluid obtain from right ovary; FF2 follicular fluid obtain from left ovary, FF - follicular fluid, $\mathrm{BE}$ - base excess 


\section{Discussion}

The aim of the study was to compare differences of physiological ABB indices in FF and $\mathrm{VB}$ and to evaluate $\mathrm{ABB}$ indices in FF collected from follicles of different origin in dairy cows and heifers. The results showed significantly higher values of $\mathrm{pH}$, lower $\mathrm{pCO}_{2}$, higher $\mathrm{pO}_{2}$, lower $\mathrm{HCO}_{3}^{-}$in $\mathrm{FF}$ obtained from oestrous and dominant follicles and lower $\mathrm{BE}$ in $\mathrm{FF}$ obtained from oestrous follicles compared to blood. Lower $\mathrm{pCO}_{2}$, higher $\mathrm{pO}_{2}$, and lower $\mathrm{HCO}_{3}^{-}$were determined in $\mathrm{FF}$ obtained from oestrous follicles after stimulation with FSH compared to $\mathrm{VB}$, whereas values of $\mathrm{pH}$ and $\mathrm{BE}$ were not different. However, the numerical mean value of $\mathrm{pH}$ in the $\mathrm{FF}$ from the stimulated oestrous follicles from both ovaries was higher by $0.26-0.27$ than in the blood (7.402 vs. 7.429 vs. 7.428 ), which is the same difference as in the dominant follicle (7.350 vs. 7.377$)$, and more than in the non-stimulated oestrous follicles, with a numerical increase of 0.2 (7.378 vs. 7.398), whereas in the dominant follicles and non-stimulated follicles these differences were significant. Thus, there is a clear tendency for higher $\mathrm{pH}$ in FF from stimulated oestrous follicles.

Sequences of FF and VB samples (T0, T24, and T36) showed stable ABB values during the sampling period. Only the $\mathrm{pH}$ was increased in FF1 samples at T36, however, it was probably a response to a significant increase of $\mathrm{HCO}_{3}^{-}$and $\mathrm{BE}$ values in the blood at the same time.

Considering the limited amount of samples in individual experiments and the tight non-significant results of some relationships, the data from experiments 1 and 2 and experiments 3 and 4 were put together. Therefore, we evaluated ABB relationships between VB and FF by non-stimulated and stimulated cows, finding that the relationships were the same in these two groups. In FF was found higher $\mathrm{pH}$, lower $\mathrm{pCO}_{2}$, higher $\mathrm{pO}_{2}$, and lower $\mathrm{HCO}_{3}{ }^{-}$and lower BE compared to blood in both groups.

We suppose that the main cause of higher $\mathrm{pH}$ in $\mathrm{FF}$ is the difference in $\mathrm{pCO}$ in $\mathrm{FF}$ and VB. The Henderson-Hasselbach equation $\left[\mathrm{pH}=6.1+\log _{10}\left(\mathrm{HCO}_{3}^{-} / \alpha \times \mathrm{pCO}_{2}\right)\right]$ indicates that if the $\mathrm{HCO}_{3}^{-}$or $\mathrm{pCO}_{2}$ changes in blood, the $\mathrm{pH}$ changes as well. The follicle, as the final consumer of nutrients and therefore of oxygen, is supplied with arterial blood that has significantly higher $\mathrm{pO}_{2}$ and lower $\mathrm{pCO}_{2}$ than venous blood. Follicular fluid reflects this fact as well as the fact that follicular wall cells give their products (and thus the metabolic refuse) into the follicle cavity. Therefore, FF has to logically have $\mathrm{pCO}_{2}$ and $\mathrm{pO}_{2}$ values between arterial and venous blood values. We did not collect arterial blood, however, differences in $\mathrm{pH}$ and blood gases between FF and VB in our study are similar to previously described differences in $\mathrm{pH}$ and blood gases between arterial blood and VB (Nagy et al. 1994). The range of $\mathrm{pCO}_{2}$ and $\mathrm{pO}_{2}$ values was $5.11-5.91 \mathrm{kPa}$ and $10.64-14.10 \mathrm{kPa}$ in $\mathrm{FF}$ in our study and similar values were reported for arterial blood $(5.58 \mathrm{kPa}$ and $11.73 \mathrm{kPa})$ (Nagy et al. 1994). Values of blood gases and $\mathrm{pH}$ in VB in our study were similar to the mentioned study (Nagy et al. 1994). According to the Henderson-Hasselbach equation, the reduced $\mathrm{pCO}_{2}$ value (in the denominator of the equation) is projected at the $\mathrm{pH}$ in the $\mathrm{FF}$ (increase). The observed $\mathrm{HCO}_{3}^{-}$(in the numerator of the equation) is also lower in $\mathrm{FF}$ than in the blood, thus acting on the $\mathrm{pH}$ of the $\mathrm{FF}$ in the opposite direction to $\mathrm{pCO}_{2}$ (decrease). However, the $\mathrm{HCO}_{3}^{-}$value is lower by only $4-5 \%$ in $\mathrm{FF}$, while the $\mathrm{pCO}_{2}$ value is about $12 \%$ lower than in the $\mathrm{VB}$, therefore the resulting $\mathrm{pH}$ in FF will affect more $\mathrm{pCO}_{2}$.

Daya (1988) found higher $\mathrm{pCO}_{2}$ and lower $\mathrm{pH}$ in FF collected laparoscopically, compared to FF obtained by ultrasonography aspiration due to pneumoperitoneum. The results from those studies also indicate that oocytes in preovulatory follicles are surrounded by fluid that is more alkaline than plasma. The oocytes obtained by the laparoscopic collection with the pneumoperitoneum have a lower in vitro fertilization capacity (Boyers et al. 1987). 
Higher values of $\mathrm{pO}_{2}$ in $\mathrm{FF}$ compared to $\mathrm{VB}$ have been described by other authors. Higher values are described in cattle $(86.4 \mathrm{mmHg}$ in calculated $8.93 \mathrm{kPa}$, Berg et al. 2003; $84.4 \mathrm{mmHg}$ in calculated $11.2 \mathrm{kPa}$, Berg et al. 2005), or in human $(80-60 \mathrm{mmHg}-$ conversion of $8 \mathrm{kPa}$, Fisher et al. 1992). Some authors report even higher values of $\mathrm{pO}_{2}$ in FF (in humans, $126.1 \mathrm{mmHg}$ - calculated $13 \mathrm{kPa}$, Imoedemhe et al. 1993; in cattle, 27-39 $\mathrm{kPa}$, Hussein et al. 2013), but these high values are probably results of a preanalytical error (Redding et al. 2008). The sampling in our study was carried out anaerobically using a device specially developed for this purpose. The samples were collected using glass syringes, immediately placed on ice and examined as quickly as possible. Therefore we suppose that possible pre-analytical changes in $\mathrm{ABB}$ variables were minimized, and changes in $\mathrm{pCO}_{2}, \mathrm{pO}_{2}$, and $\mathrm{pH}$ in the follicular fluid compared to the blood were the results of follicle metabolism. In the fourth experiment, samples were determined almost immediately after collection, and $\mathrm{pCO}_{2}$ in $\mathrm{FF}$ was slightly lower compared to other experiments. Conversely, Berg et al. (2003) describe a decreasing of $\mathrm{pCO}_{2}$ values if the FF sample is left for $4 \mathrm{~h}$ at room temperature.

Base excess was quite a variable parameter in our experiment. Its values were either the same as in the blood or lower. In general, BE is dependent on the overall metabolic status of the organism. Base excess is currently defined as the amount of strong acid or base required to maintain blood $\mathrm{pH} 7.40$ at $37^{\circ} \mathrm{C}$ and $\mathrm{pCO} 2$ of $5.33 \mathrm{kPa}$ (Constable 2008). It is, therefore, questionable how far these buffer systems operate in FF.

The interpretation of results in our study and its confrontation with available literature is not easy. The recovery of FF for $\mathrm{ABB}$ and gas analysis from live animals is rarely described. Methodology in the studies used different data sets and different techniques for FF collection. The technique appears to be crucial, as was demonstrated experimentally (Cech et al. 2013). It is necessary to avoid contact between the sample and the air (so-called "air contamination"). This is manifested by an increase in $\mathrm{pO}_{2}$, as can be seen in our study in Table 5 . There is clearly higher $\mathrm{pO}_{2}$ in $\mathrm{FF}$ collected from the right ovary at T36 - about $14 \mathrm{kPa}$, thus $2 \mathrm{kPa}$ more than in previous samplings. This is why the $\mathrm{pCO}_{2}$ is slightly decreased compared to values found at time T24. Furthermore, the fluctuation of ABB to the acidosis in VB and FF was observed at T24, as seen in Tables 5, 6 and 7 as a decrease of $\mathrm{BE}$ values followed by a return back at T36. A combination of this fluctuation together with an unsure FF1 collection probably resulted in the $\mathrm{pH}$ increase at T36. Of course, it is valid only for FF1 (right ovary). Because the follicular population of both ovaries was the same, an explanation of this event is only by the questionable quality of FF1 sampling at T36. Even if a special device for FF collection (Cech et al. 2013) was used, a higher air contamination of the sample can occur due to the higher speed of aspiration, insufficient needle attachment or movement of the animal at a critical phase of the aspiration.

The results of our study showed that higher $\mathrm{pH}$, lower $\mathrm{pCO}_{2}$, higher $\mathrm{pO}_{2}$, lower $\mathrm{HCO}_{3}^{-}$and lower $\mathrm{BE}$ were detected in $\mathrm{FF}$ from dominant, oestrous and stimulated oestrous follicles compared to $\mathrm{VB}$, and these relationships did not change in stimulated follicles during $36 \mathrm{~h}$ of observation. Thus, we can state that relationships between the ABB indices in blood and FF are constant, independent of the stage of follicular development and not affected by FSH stimulation.

\section{Conflict of Interest}

None of the authors has any conflict of interest to declare.

\section{Acknowledgement}

The study was supported by the Internal Grant Agency of the University of Veterinary and Pharmaceutical Sciences Brno, No. 120/2018/FVL. 


\section{References}

Berg DK, Beaumont SE, Berg MC, Hull CD, Tervit HR 2003: Oxygen and carbon dioxide tension in days 14-15 dominant bovine follicles measured in vivo or 4 hours post-mortem. Theriogenology 59: 406

Berg MC, Beaumont SE, Peterson AJ, Berg DK 2005: A procedure combining iSTAT ${ }^{\circledR}$ analysis with OPU to study bovine follicular environments. Reprod Fertil Dev 17: 318-319

Boyers SP, Lavy G, Russel JB, De Cherney AH 1987: A paired analysis of in vitro fertilization and cleavage rates of first- versus last-recovered preovulatory human oocytes exposed to varying intervals of $100 \% \mathrm{CO} 2$ pneumoperitoneum and general anesthesia. Fertil Steril 48: 969-974

Cech S, Dolezel R, Lopatarova M, Pechova A 2007: Acid-base balance of follicular fluid in dairy heifers. Reprod Domest Anim 42: 113

Cech S, Indrova E, Lopatarova M, Mala J, Pechova A, Dolezel R 2011: Limitations of ultrasound guided follicular aspiration for analysis of follicular fluid in dairy cattle. Acta Vet Brno 80: 179-184

Cech S, Dolezel R, Holickova K, Indrova E, Kochova T, Lopatarova M, Mala J, Pechova A, Zavadilova M, Zilka L 2013: A new device for the aspiration of follicular fluid for acid-base balance in cattle. Vet Med 58: 527-534

Constable PD 2008: Strong ion difference theory: a revolutionary approach to the diagnosis and treatment of acidbase abnormalities in cattle. Proc. XXV. Jubilee World Buiatrics Congress 28-33

Daya S 1988: Follicular fluid $\mathrm{pH}$ changes following intraperitoneal exposure of Graafian follicles to carbon dioxide: a comparative study with follicles exposed to ultrasound. Hum Reprod 3: 727-730

de Castro e Paula LA, Andrzejewski J, Julian D, Spicer LJ, Hansen PJ, 2008: Oxygen and steroid concentrations in preovulatory follicles of lactating dairy cows exposed to acute heat stress. Theriogenology 69: 805-813

Eissa HM 1996: Concentrations of steroids and biochemical constituents in follicular fluid of buffalo cows during different stages of the oestrous cycle. Br Vet J 152: 573-581

Fischer B, Kiinzel W, Kleinstein J, Gips H 1992: Oxygen tension in follicular fluid falls with follicle maturation. Eur J Obstet Gynecol Reprod Biol. 43: 39-43

Gérard N, Loiseau S, Duchamp G, Seguin F 2002: Analysis of the variations of follicular fluid composition during follicular growth and maturation in the mare using proton nuclear magnetic resonance ( $\left.{ }^{1} \mathrm{H} M N R\right)$. Reproduction 124: 241-248

Hafez ESE 2000: Reproduction in farm animals. $7^{\text {th }}$ edn, Lea a Febiger, Philadelphia, p. 505

Hussein HA, Boryczko Z, Bostedt H 2013: Acid-base parameters and steroid concentrations in preovulatory follicles and plasma of lactating dairy cows with spontaneous and synchronized oestrus or follicular cyst. Reprod Domest Anim 48: 833-839

Imoedemhe DAG, Chan RCW, Ramadan IAG, Sigue AB 1993: Changes in follicular fluid gas and pH during carbon dioxide pneumoperitoneum for laparoscopic aspiration and their effect on human oocyte fertilizability. Fertil Steril 59: 177-182

Indrova E, Dolezel R, Novakova-Mala J, Pechova A, Zavadilova M, Cech S 2017: Impact of acute metabolic acidosis on the acid-base balance in follicular fluid and blood in dairy cattle. Theriogenology 89: 41-46

Kohram H, Bousquet D, Durocher J, Guilbault LA 1998: Alteration of follicular dynamics and superovulatory responses by gonadotropin releasing hormone and follicular puncture in cattle: a field trial. Theriogenology 49: $1165-1174$

Landau S, Braw-Tal R, Kaim M, Bor A, Bruckental I 2000: Preovulatory follicular status and diet affect the insulin and glucose content of follicles in high-yielding dairy cows. Anim Reprod Sci 64: 181-197

Moallem U, Folman Y, Bor A, Arav A, Sklan D 2011: Effect of calcium soaps of fatty acids and administration of somatotropin on milk production, preovulatory follicular development, and plasma and follicular fluid lipid composition in high yielding dairy cows. J Dairy Sci 82: 2358-2368

Nagy O, Sedovic M, Slanina L 1994: Central and peripheral arterial and venous blood in cattle with respect to acid-base balance evaluations. Vet Med-Czech 39: 1-9

Pechova A, Hofirek B, Pavlata L, Dvorak R 2009: Produkční a preventivní medicína v chovech skotu. In: Hofirek B, editor. Nemoci skotu, $1^{\text {st }}$ edn. Brno: Noviko, a.s., p. 1042

R Core Team 2017: R: A language and environment for statistical computing. R Foundation for Statistical Computing, Vienna, Austria

Redding GP, Bronlund JE, Hart AL 2008: Theoretical investigation into the dissolved oxygen levels in follicular fluid of the developing human follicle using mathematical modeling. Reprod Fertil Dev 20: 408-417

Reece WO 2015: Fundamental of acid-base balance. In: Reece W.O, editor. Dukes' Physiology of Domestic Animals, $13^{\text {th }}$ edn. Cornell University Press, Ithaca, NY, pp. 137-148

Shalgi R, Kraicer PF, Soferman N 1972: Gases and electrolytes of human follicular fluid. J Reprod Fertil 28: 335-340

Shehab-El-Deen MAMM, Leroy JLMR, Fadel MS, Saleh SYA, Maes D, Van Soom A 2010: Biochemical changes in the follicular fluid of the dominant follicle of high producing dairy cows exposed to heat stress early postpartum. Anim Reprod Sci 117: 189-200

Vos PLAM, de Loos FAM, Pieterse MC, Bevers MM, Taverne MAM, Dieleman SJ 1994: Evaluation of transvaginal ultrasound-guided follicle puncture to collect oocytes and follicular fluids at consecutive times relative to the preovulatory LH surge in eCG/ PG-treated cows. Theriogenology 41: 829-840

Walters AH, Pryor AW, Bailey TL, Pearson RE, Gwazdauskas FC 2002: Milk yield, energy balance, hormone, follicular and oocyte measures in early and mid-lactation Holstein cows. Theriogenology 57: 949-961 